\title{
DEVELOPMENT OF PERIRADICULAR LESIONS IN NORMAL AND DIABETIC RATS
}

\author{
DESENVOLVIMENTO DE LESÕES PERIRRADICULARES \\ EM RATOS NORMAIS E DIABÉTICOS
}

Luci ARMADA-DIAS ${ }^{1}$, Jorge BREDA², José Claudio PROVENZANO ${ }^{3}$, Marisa BREITENBACH ${ }^{1}$, Isabela das Neves RÔÇAS ${ }^{4}$, Sérgio Márcio Motta GAHYVA ${ }^{4}$, José Freitas SIQUEIRA JUNIOR ${ }^{4}$

1- PhD, Professor of Physiology, Dental School, Estácio de Sá University, Rio de Janeiro, RJ, Brazil.

2- Undergraduate student, Dental School, Estácio de Sá University, Rio de Janeiro, RJ, Brazil.

3- DDS, Graduate student, Master's Program in Endodontics, Dental School, Estácio de Sá University, Rio de Janeiro, RJ, Brazil.

4- PhD, Professors of Endodontics, Dental School, Estácio de Sá University, Rio de Janeiro, RJ, Brazil.

Corresponding address: José F. Siqueira Jr - Av. Almte Ary Parreiras 311 / 1001, Icaraí, Niterói, RJ - Brazil Cep.: 24230-322

Tel: 21 8874-1022 - FAX: 21 2503-7289 ramal 223 - e-mail: siqueira@estacio.br

Received: March 27, 2006 - Modification: July 18, 2006 - Accepted: August 17, 2006

\begin{abstract}
$E$

vidence suggests that diabetic patients are more significantly affected by problems of endodontic origin. This study sought to radiographically and histologically examine the development of periradicular inflammation in control and in diabetic rats after induction of pulpal infection. The pulps of the mandibular first molars of normal and streptozotocin-induced diabetic rats were exposed and left in contact with their oral cavities for 21 and 40 days. Afterwards, the animals were sacrificed, the mandibles were surgically removed, fixed in formalin and then radiographed in a standardized position. The radiographic images of the periradicular lesions were scanned and computerized images were evaluated for the total area of the lesions using a specific software. Representative specimens were also prepared for histopathological analysis. Radiographic analysis revealed that diabetic rats presented significantly larger periradicular lesions when compared with control rats, regardless of the experimental period $(\mathrm{p}<0.05)$. Histopathological examination of representative specimens revealed larger periradicular lesions and more severe inflammatory exudate in the group of diabetic rats when compared with the control group. Data from the present study indicated that diabetic rats can be more prone to develop large periradicular lesions, possibly due to reduction in the defense ability against microbial pathogens.

Uniterms: Endodontic infection; Apical periodontitis; Diabetes.
\end{abstract}

\section{RESUMO}

$E$

vidências indicam que pacientes diabéticos são mais significativamente afetados por problemas de origem endodôntica. Este estudo avaliou radiográfica e histologicamente o desenvolvimento de inflamação perirradicular em ratos controle e diabéticos depois da indução de infecção pulpar. As polpas dos primeiros molares inferiores de ratos normais ou diabéticos foram expostas e deixadas em contato com a cavidade oral por 21 e 40 dias. Em seguida, os animais foram sacrificados, as mandíbulas removidas cirurgicamente, fixadas em formalina e depois radiografadas em posição padronizada. As imagens radiográficas das lesões perirradiculares foram escaneadas e as imagens computadorizadas avaliadas quanto à área total das lesões usando software específico. Espécimes representativos foram preparados também para análise histológica. A análise radiográfica revelou que os ratos diabéticos apresentaram lesões periradiculares significativamente maiores quando comparados com os ratos normais, independentemente do período experimental $(\mathrm{p}<0.05)$. O exame histológico de espécimes representativos revelou lesões perirradiculares mais extensas e com exsudato inlflamatório severo no grupo de ratos diabéticos quando comparado com o grupo controle. Os dados deste estudo indicam que ratos diabéticos podem ser mais propensos a desenvolver lesões perirradiculares extensas, possivelmente devido à diminuição da capacidade de defesa contra patógenos microbianos. Unitermos: Infecção endodôntica; Periodontite apical; Diabetes. 


\section{INTRODUCTION}

Diabetes mellitus is a disorder characterized by altered glucose tolerance or impaired lipid and carbohydrate metabolism. Type 1 diabetics experience $\beta$ cell destruction of the islets of Langerhans of the pancreas, which may lead to an absolute insulin deficiency. Those individuals are dependent on insulin for metabolic control of their disease. Type 2 diabetes mellitus patients experience impaired cellular sensitivity to insulin (insulin resistance), with or without insulin deficiency. Estimates indicate that 12 to 15 million individuals have diabetes in the United States ${ }^{1,10,11}$.

Prevalence, severity and progression of periodontal disease have been shown to increase in diabetic subjects ${ }^{2,3}$. Loss of periodontal attachment occurs more frequently and more extensively in moderately and poorly controlled diabetic patients than those under proper control ${ }^{14}$. It has been suggested that several factors may contribute to the development of periodontitis in patients with diabetes mellitus, including defective polymorphonuclear leukocyte function, altered collagen metabolism, pathological vascular change, compromised wound healing potential and microbiological imbalance ${ }^{15}$.

Diabetes may also influence the development and the course of periradicular diseases. In diabetic patients, the initial periradicular lesion may increase in size, even with proper endodontic treatment ${ }^{13}$. Diabetics also had about twice the rate of flare-ups compared to non-diabetics ${ }^{5,7}$. Moreover, when cases with preoperative periradicular lesions were investigated, diabetics had a much lower percentage of successful cases compared with nondiabetics $^{5}$. All these findings strongly suggest that diabetic patients are more prone to be affected by problems of endodontic origin. Thus, the purpose of this study was to radiographically and histologically examine the development of periradicular inflammation in control and in diabetic rats after induction of pulpal infection.

\section{MATERIALAND METHODS}

Approval for the study protocol was obtained from the Ethics Committee of Estácio de Sá University, Rio de Janeiro, RJ, Brazil. Forty male 3-month old Wistar rats weighing from 200 to 220 g were used for this study. The animals were equally divided into two groups: one composed of 20 normal rats (control group); and the other composed of 20 rats with streptozotocin-induced diabetes. For diabetes induction, rats received a single intraperitoneal dosage of streptozotocin (45 mg/Kg body weight) dissolved in $50 \mathrm{mM}$ citrate buffer ( $\mathrm{pH} 4.5$ ). Streptozotocin is selectively cytotoxic to the islet cells in the pancreas and by using this drug diabetes can be induced in a controlled manner. Normal rats received an equivalent volume of diluent (citrate buffer). After 48 hr, glycemia was measured and animals with blood glucose levels higher than $250 \mathrm{mg} / \mathrm{dL}$ were selected and this date considered as the first day of disease (diabetes).

Animals were anesthetized with intraperitoneal injection of pentobarbital $(0.08 \mathrm{~mL} / 100 \mathrm{~g}$ body weight $)$ after 7 days of diabetes evolution and the pulps of the mandibular first molars of all animals (control and diabetic rats) were exposed with a size $1 / 2$ round steel bur in high-speed rotation. Pulps were left open to the oral cavity. Ten animals per group were killed by cervical dislocation at 21 and 40 days after pulp exposure. Mandibles were then surgically removed, fixed in $10 \%$ neutral-buffered formalin solution for 2 days and then radiographed in a standardized position. Exposure parameters were as follows: $60 \mathrm{kVp}$ and $10 \mathrm{~mA}$, intraoral dental radiographic film (Kodak Ultra-speed), focus-film distance of $15 \mathrm{~cm}$, exposure time $0.3 \mathrm{~s}$ and a constant incidence of the central ray perpendicular to the film. The same radiographic device was used to radiograph all specimens. Exposed films were then automatically processed.

The radiographic images of the periradicular lesions were scanned (Scan Jet 3c-Hewlett-Packard, Dallas, TX, USA), transferred to a personal computer and the total area of the lesions measured using Global Lab Image software (Data Translation Inc., Dallas, TX, USA). The results were evaluated by the Mann-Whitney test comparing pairs of groups. Significance level was established at $5 \%(\mathrm{p}<0.05)$.

Three representative specimens of each group and per evaluation period were randomly selected and prepared for histopathological analysis. Mandibles were resected, fixed in neutral buffered formalin solution and decalcified under agitation in 5\% buffered EDTA ( $\mathrm{pH} 7.0$ ), which was renewed every 2 days. Blocks containing the experimental roots and surrounding periradicular tissues were embedded in paraffin, and serial longitudinal sections with average thickness of 6 mm were obtained. All sections of each specimen were stained with hematoxylin and eosin, examined under a light microscope and classified according to the intensity of inflammatory infiltrate (absent, discrete, moderate or severe) and width of the periodontal ligament space (normal; widened but no detectable bone loss; detectable loss of apical bone; and severe destruction of apical bone). Lesions were also categorized as granuloma or cyst, the latter only when a distinct epithelium-lined cavity was discernible.

\section{RESULTS}

Diabetic rats showed lower body weight than the controls and glycemia was significantly higher in the diabetes group ( $\mathrm{p}<0.05$, Mann-Whitney test) (Table 1$)$. Two rats died during the experimental period, one from each group. Radiographic analysis revealed that diabetic rats presented significantly larger periradicular lesions when compared with control rats, regardless of the experimental period ( $\mathrm{p}<0.05$, Mann-Whitney test) (Figure 1). There was also a significant difference when comparing the size of periradicular lesions in control rats sacrificed in 21 and 40 days ( $<0.05$, Mann-Whitney test) (Figure 1$)$. The longer the period, the larger the lesions.

Histopathological examination of representative specimens revealed that periradicular lesions developed in some specimens even before the pulp was totally necrotic. 
Large periradicular lesions and severe inflammatory exudate were observed more frequently in the group of diabetic rats than in controls (Figure 2). All examined lesions but one were diagnosed as periradicular granuloma. In one specimen of a diabetic rat sacrificed after 40 days of pulpal exposure, a periradicular cyst was formed (Figure 3).

\section{DISCUSSION}

In the present study, diabetes was induced by means of streptozotocin, which is selectively cytotoxic to the islet cells in the pancreas. The advantages of using the streptozotocin refer to the fact that diabetes can be induced in a controlled manner in all animals. Furthermore, animals in the diabetes and non-diabetes groups can have the same genetic background ${ }^{7}$. Our overall results are in agreement with the study of Kohsaka et al. ${ }^{8}(1996)$, which histologically and histometrically demonstrated that induced periradicular lesions in diabetic rats had larger size than in non-diabetic
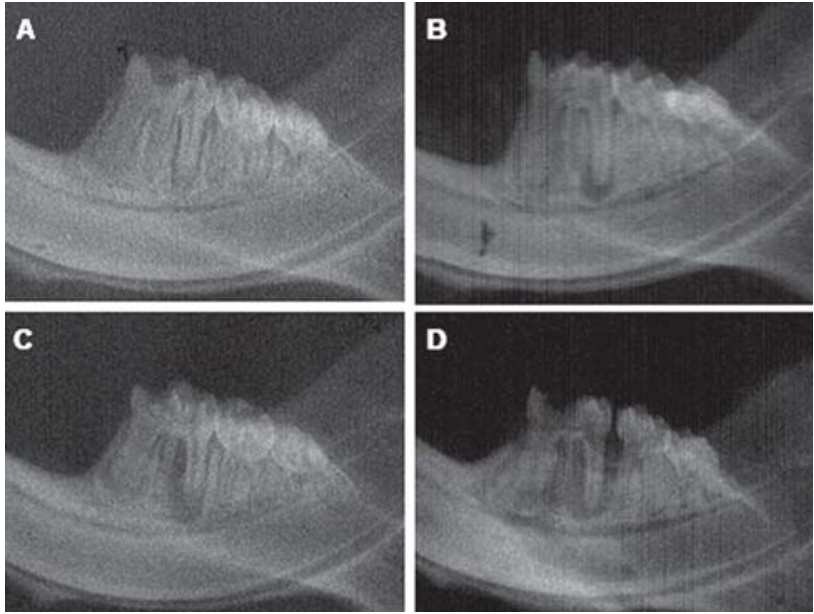

FIGURE 1- Radiographs of representative specimens of each group. A and B, control group after 21 and 40 days of pulpal exposure, respectively. $C$ and $D$, experimental group (diabetic rats) after 21 and 40 days of pulpal exposure, respectively controls.

The radiographic analysis performed in the present study revealed that periradicular lesions were significantly larger in the 40-day period than in the 21-day period, even in nondiabetic animals. In some cases, periradicular lesions were detected long before the pulps were totally necrotic. This was in agreement with Yamasaki, et al. ${ }^{16}$ (1994).

Fouad, et al. ${ }^{4}$ (2002) investigated the root canal microbiota of diabetics and non-diabetics using the polymerase chain reaction and reported that there was a

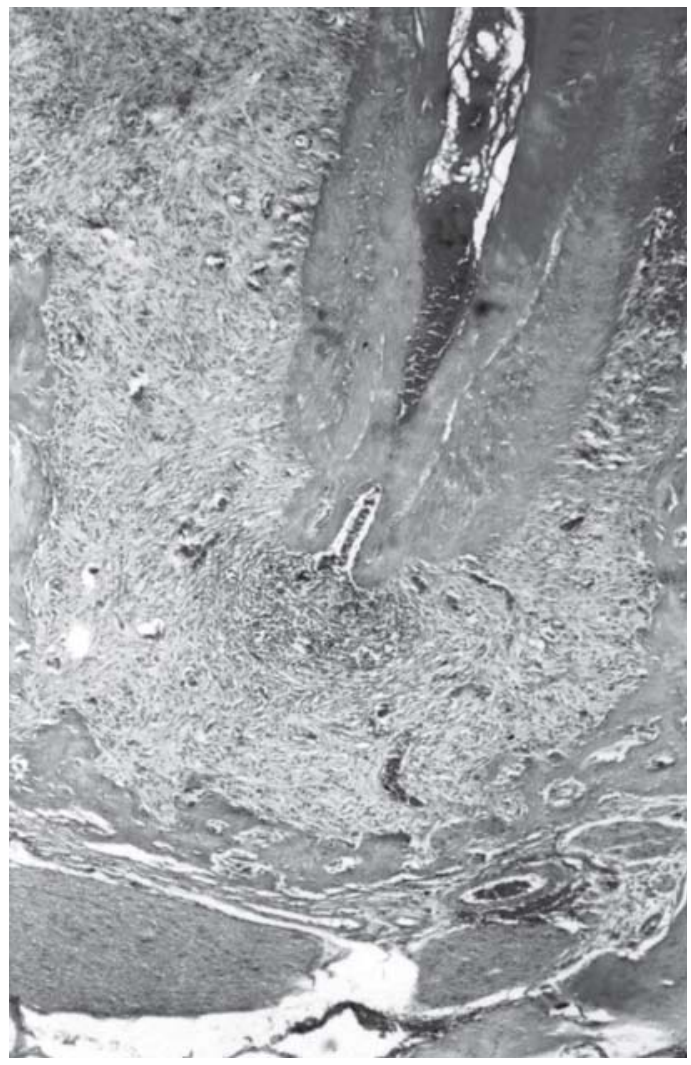

FIGURE 2- Large periradicular lesion (granuloma) in a diabetic rat after 40 days of pulpal exposure. Note the intense inflammatory infiltrate concentrated near the apical foramen (hematoxylin and eosin, original magnification 100x)

TABLE 1- Body weight and glycemia in control and diabetic rats

\begin{tabular}{lllll}
\hline Groups & $\begin{array}{c}\text { Body weight-a } \\
(\mathbf{g})\end{array}$ & $\begin{array}{c}\text { Body weight-b } \\
\mathbf{( g )}\end{array}$ & $\begin{array}{c}\text { Glycemia-a } \\
(\mathbf{m g} / \mathbf{d L})\end{array}$ & $\begin{array}{c}\text { Glycemia-b } \\
(\mathbf{m g} / \mathbf{d L})\end{array}$ \\
\hline Control- 21 & $214.8 \pm 8.2$ & $231.8 \pm 6.3$ & $95 \pm 3.2$ & $104 \pm 2.5$ \\
Control- 40 & $222.8 \pm 3.8$ & $247.8 \pm 5.4$ & $94.4 \pm 4.6$ & $97 \pm 3.9$ \\
DM-21 & $213 \pm 6.6$ & $195.7 \pm 4.4^{*}$ & $390 \pm 32.1^{*}$ & $439 \pm 18.4^{\star}$ \\
DM-40 & $212.4 \pm 7.6$ & $176.5 \pm 9.7^{*}$ & $430.8 \pm 19.32^{*}$ & $489 \pm 9.3^{*}$ \\
\hline
\end{tabular}

Values are expressed as mean \pm standard deviation; Control- 21= normal rats sacrificed at 21 days; Control-40= normal rats sacrificed at 40 days. DM-21= diabetic animals sacrificed at 21 days; DM-40= diabetic animals sacrificed at 40 days; Body weight and glycemia: $a=$ measurements obtained after 48 hours of disease induction (considered as the first day of disease); $b=$ measurements obtained at the sacrifice day. ${ }^{*} p<0.05$ vs respective control groups (Mann-Whitney test). 
positive, yet non-significant, association between diabetes and the presence of Porphyromonas endodontalis and Porphyromonas gingivalis. The number of different microorganisms detected per specimen was, on average, higher in diabetics than in non-diabetics, but the differences were not statistically significant. In another study ${ }^{6}$, the same group found that Eubacterium infirmum was significantly more found in root canals of diabetic patients than in nondiabetic individuals. Based on those studies, one can surmise that there is a potential increased prevalence of some virulent endodontic pathogens in root canals of diabetic patients. Such a higher prevalence of endodontic pathogens may be one of the possible reasons why periradicular lesions are more pronounced in diabetics than in non-diabetics.

Fouad and Burleson ${ }^{5}$ (2003) used a custom-built electronic record system to investigate endodontic diagnostic and treatment outcome data in patients with and without diabetes. A total of 5,494 cases (284 diabetic patients) were treated, and 540 cases (73 diabetic patients) had followup data two years or more postoperatively. There was a trend toward increased symptomatic periradicular disease in patients with diabetes who received insulin, as well as flare-ups in all patients with diabetes. Two years or longer postoperatively, 68\% of cases followed were successful. They found that patients with diabetes had a reduced likelihood of success of endodontic treatment in cases with preoperative periradicular lesions.

Diabetes is associated with innumerous complications,

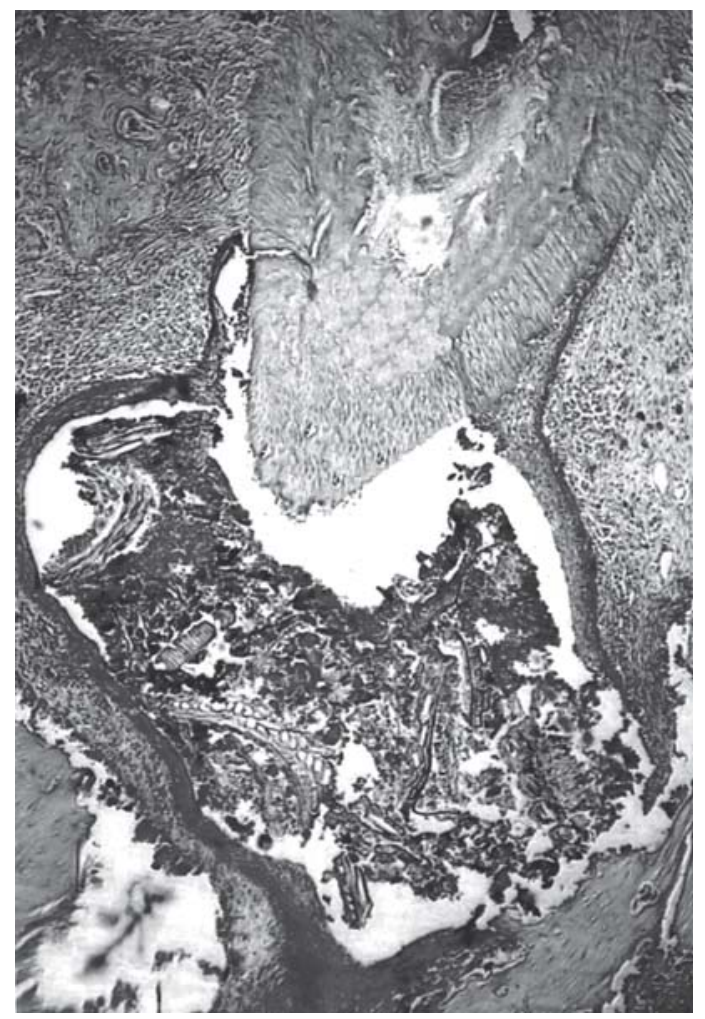

FIGURE 3- Periradicular cyst formation in a diabetic rat after 40 days of pulpal exposure. Note the presence of food and tissue debris in the cyst lumen (hematoxylin and eosin, original magnification 100x) and different mechanisms are likely to account for them. The direct toxic effects of elevated blood glucose can have important pathological consequences. Nonetheless, current evidence suggests that indirect effects of hyperglycemia, such as the formation of irreversible advanced glycation end-products (AGE), are implicated in the induction of toxic effects $^{9}$. The interaction of AGEs with their receptors (RAGE) appears to mediate chronic cellular perturbation and disfunction ${ }^{1,12}$. Altered host response to infection occurs in diabetic individuals and may be related to the accumulation of AGEs and their interaction with RAGE in tissues.

In fact, AGEs form and accumulate in tissues in different conditions, including aging, renal failure and diabetes. Under normal circumstances, RAGE is present at low levels in a number of cell types, including endothelial cells and monocytes. In perturbed states, such as diabetes, the expression of RAGE on critical target cells is significantly enhanced. Accumulation of AGEs in tissues and their interaction with RAGE can significantly alter tissue ability to respond to infection. Alterations include increase in the vascular permeability and enhanced expression of adhesion molecules on endothelial cells; attraction and activation of macrophages, leading to the release of proinflammatory cytokines, such as interleukin (IL)-1 $\beta$, IL-6 and tumor necrosis factor (TNF)- $\alpha$, and matrix metalloproteinases; action on fibroblasts, inducing increased activity of matrix metalloproteinases and impaired collagen synthesis. Therefore, interaction of AGEs with RAGE expressed on endothelial cells, macrophages and fibroblasts can lead to an exaggerated and sustained response to infection and diminished reparative response. As a consequence, when infection occurs in an AGE-enriched environment, accelerated and excessive tissue destruction may be observed $^{9}$.

Our data lend additional support to the assertion that diabetes mellitus induces reduction in the host defense ability against microbial agents. The results of this study suggest that diabetic patients can be more prone to develop large periradicular lesions. As discussed above, the reasons for this can be manifold. Our results and those from the endodontic literature indicate that special care should be taken during endodontic treatment in diabetic patients and all efforts should be directed towards prevention and control of endodontic infection, with proper antimicrobial approaches.

\section{ACKNOWLEDGMENTS}

We would like to thank Eliane Aparecida Batista for valuable technical assistance.

\section{REFERENCES}

1- Baynes J. Role of oxidative stress in development of complications in diabetes. Diabetes. 1991;40:405-12. 
2- Cianciola L, Park B, Bruck E, Mosorich L, Genco RJ. Prevalence of periodontal disease in insulin-dependent diabetes mellitus. J Am Dent Assoc. 1982;104:653-60.

3- Emrich LJ, Shlossman M, Genco RJ. Periodontal disease in insulindependent diabetes mellitus. J Periodontol. 1991;62:123-30.

4- Fouad AF, Barry J, Caimano M, Clawson M, Zhu Q, Carver R, Hazlett K, Radolf JD. PCR-based identification of bacteria associated with endodontic infections. J Clin Microbiol. 2002;40:3223-31.

5- Fouad AF, Burleson J. The effect of diabetes mellitus on endodontic treatment outcome: data from an electronic patient record. J Am Dent Assoc. 2003;134:43-51.

6- Fouad AF, Kum K-Y, Clawson ML, Barry J, Abenoja C, Zhu Q, Caimano M, Radolf JD. Molecular characterization of the presence of Eubacterium spp. and Streptococcus spp. in endodontic infections. Oral Microbiol Immunol. 2003;18:249-55.

7- Fouad AF. Diabetes mellitus as a modulating factor of endodontic infections. J Dent Educ. 2003;67:459-67.

8- Kohsaka T, Kumazawa M, Yamasaki M, Nakamura H. Periapical lesions in rats with streptozotocin-induced diabetes. J Endod. 1996;22:418-21.

9- Lalla E, Lamster IB, Drury S, Fu C, Schmidt AM. Hyperglycemia, glycoxidation and receptor for advanced glycation endproducts: potential mechanisms underlying diabetic complications, including diabetes-associated periodontitis. Periodontol. 2000 2000;23:50-62.

10 - Leibson C, Milton LJ III, Palumbo VJ. Temporal trends in diabetes incidence and prevalence. Diabetes Care 1996;19:807-11.

11- Rees TD. Periodontal management of the patient with diabetes mellitus. Periodontol. 2000 2000;23:63-72.

12 - Ruderman N, Williamson J, Brownlee M. Glucose and diabetic vascular disease. FASEB J. 1992;6:2905-14.

13- Seltzer S. Endodontology. Biologic considerations in endodontic procedures. 2nd ed., Philadelphia: Lea \& Febiger; 1988.

14- Tervonen T, Oliver R. Long-term control of diabetes mellitus and periodontitis. J Clin Periodontol. 1993;20:431-5.

15- The American Academy of Periodontology. Position paper: Diabetes and periodontal diseases. J Periodontol. 1996;67:166-76.

16- Yamasaki M, Kumazawa M, Kohsaka T, Nakamura H, Kameyama Y. Pulpal and periapical tissue reactions after experimental pulpal exposure in rats. J Endod. 1994;20:13-7. 